\title{
Front Matter: Volume 9964
}

, "Front Matter: Volume 9964," Proc. SPIE 9964, Advances in Laboratorybased X-Ray Sources, Optics, and Applications V, 996401 (22 December 2016); doi: 10.1117/12.2256413

EDIE Event: SPIE Optical Engineering + Applications, 2016, San Diego, California, SPIE. United States 


\title{
PRO CEEDINGS OF SPIE
}

\section{Advances in Laboratory-based $X$-Ray Sources, Optics, and Applications V}

\author{
Ali M. Khounsary \\ Gert E. van Dorssen \\ Editors
}

30-31 August 2016

San Diego, Califomia, United States

Sponsored and Published by

SPIE 
The papers in this volume were part of the technical conference cited on the cover and title page. Papers were selected and subject to review by the editors and conference program committee. Some conference presentations may not be available for publication. Additional papers and presentation recordings may be available online in the SPIE Digital Library at SPIEDigitallibrary.org.

The papers reflect the work and thoughts of the authors and are published herein as submitted. The publisher is not responsible for the validity of the information or for any outcomes resulting from reliance thereon.

Please use the following format to cite material from these Proceedings:

Author(s), "Title of Paper," in Advances in Laboratory-based X-Ray Sources, Optics, and Applications V, edited by Ali M. Khounsary, Gert E. van Dorssen, Proceedings of SPIE Vol. 9964 (SPIE, Bellingham, WA, 2016) Six-digit Article CID Number.

ISSN: 0277-786X

ISSN: 1996-756X (electronic)

ISBN: 9781510603196

ISBN: 9781510603202 (electronic)

Published by

SPIE

P.O. Box 10, Bellingham, Washington 98227-0010 USA

Telephone +1 3606763290 (Pacific Time) · Fax +1 3606471445

SPIE.org

Copyright @ 2016 , Society of Photo-Optical Instrumentation Engineers.

Copying of material in this book for internal or personal use, or for the internal or personal use of specific clients, beyond the fair use provisions granted by the U.S. Copyright Law is authorized by SPIE subject to payment of copying fees. The Transactional Reporting Service base fee for this volume is $\$ 18.00$ per article (or portion thereof), which should be paid directly to the Copyright Clearance Center (CCC), 222 Rosewood Drive, Danvers, MA 01923. Payment may also be made electronically through CCC Online at copyright.com. Other copying for republication, resale, advertising or promotion, or any form of systematic or multiple reproduction of any material in this book is prohibited except with permission in writing from the publisher. The CCC fee code is 0277-786X/16/\$18.00.

Printed in the United States of America.

Publication of record for individual papers is online in the SPIE Digital Library.

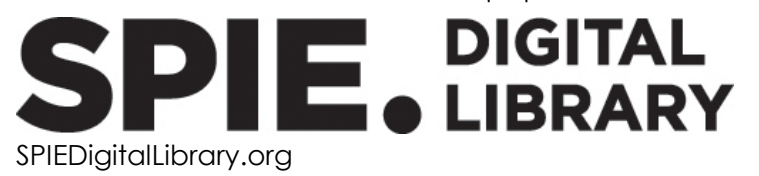

Paper Numbering: Proceedings of SPIE follow an e-First publication model. A unique citation identifier (CID) number is assigned to each article at the time of publication. Utilization of CIDs allows articles to be fully citable as soon as they are published online, and connects the same identifier to all online and print versions of the publication. SPIE uses a six-digit CID article numbering system structured as follows:

- The first four digits correspond to the SPIE volume number.

- The last two digits indicate publication order within the volume using a Base 36 numbering system employing both numerals and letters. These two-number sets start with 00, 01, 02, 03, 04, $05,06,07,08,09,0 A, 0 B \ldots$. 0Z, followed by 10-1Z, 20-2Z, etc. The CID Number appears on each page of the manuscript. 


\title{
Contents
}

\author{
$\checkmark$ Authors \\ vii Conference Committee
}

\section{SESSION 1 NOVEL LABORATORY X-RAY SOURCES I}

996402 A compact, coherent light source system architecture [9964-2]

$996404 \quad$ Advanced controls for light sources [9964-4]

SESSION 2 NOVEL LABORATORY X-RAY SOURCES II

996405 Image-based characterization of microfocus x-ray target failure [9964-5]

996406 Simulations of laser undulators [9964-6]

996408 A case for ZnO nanowire field emitter arrays in advanced $\mathrm{x}$-ray source applications [9964-8]

\section{SESSION 3 LABORATORY-BASED X-RAY OPTICS}

996409 Development of polycapillary x-ray optics for x-ray spectroscopy [9964-9]

$99640 \mathrm{~A}$ Large field-of-view asymmetric masks for high-energy $\mathbf{x}$-ray phase imaging with standard $x$-ray tube [9964-10]

\section{SESSION 4 LABORATORY-BASED X-RAY APPLICATIONS}

9964 OE Simulation tools for analyzer-based x-ray phase contrast imaging system with a conventional $x$-ray source [9964-13]

9964 OF X-ray phase scanning setup for non-destructive testing using Talbot-Lau interferometer [9964-14]

9964 OG High-resolution radiography of thick steel objects using an all-laser-driven MeV-energy $\mathrm{x}$ ray source [9964-15]

9964 Ol Laboratory-based $\mathrm{x}$-ray phase-contrast tomography enables 3D virtual histology [9964-19] 
$99640 \mathrm{~J}$ Laboratory and synchrotron tests of two-dimensional parabolic $\mathbf{x}$-ray compound refractive lens made of single-crystal diamond [9964-17]

Proc. of SPIE Vol. $9964996401-4$

Downloaded From: https://www.spiedigitallibrary.org/conference-proceedings-of-spie on 26 Apr 2023 Terms of Use: https://www.spiedigitallibrary.org/terms-of-use 


\section{Authors}

Numbers in the index correspond to the last two digits of the six-digit citation identifier (CID) article numbering system used in Proceedings of SPIE. The first four digits reflect the volume number. Base 36 numbering is employed for the last two digits and indic ates the order of articles within the volume. Numbers start with $00,01,02,03,04,05,06,07,08,09,0 A, 0 B . .0 Z$, followed by 10-1Z, 20-2Z, etc.

Adams, Bemhard W., 09

Astolfo, A., OA

Attenkofer, Klaus, 09

Bachche, S., OF

Banejee, Sudeep, 0G

Barannikov, A., 0J

Bergkvist, Magnus, 08

Biedron, S. G., 02, 04, 06

Blank, V. D., 0J

Bond, J ustin L, 09

Brankov, J.G., OE

Caudevilla, Oriol, OE

Chen, Da okun, 08

Chen, J un, 08

Chen, Shouyuan, OG

Craven, Christopher A., 09

Cremer, Till, 09

Dattoli, G., 02

Denisov, V. N., 0J

DiPalma, E., 02

Edelen, A. L, 04

Einstein, J. E., 02, 06

End rizzi, M., OA

Fruhling, Colton, OG

Golovin, Grigory, OG

Haden, Daniel, OG

Haig, I., OA

Huang, Mengbing, 08

Kageyama, M., OF

Kato, K., OF

Koike, T., OF

Komilov, N. V., 0J

Krenkel, Martin, 0 I

Kuribaya shi, M., OF

Martyushov, S. Yu., 0J

Milton, S. V., 02, 04, 06

Minot, Michael J., 09

Momose, A., OF

Nonoguchi, M., OF

Olivo, A., OA

O'Mahony, Aileen, 09

Petrillo, V., 02

Polikarpov, M., 0J

Polyakov, S. N., 0]

Popecki, Mark A., 09

Price, B., OA

Quade, Felix, 0I

Raber, Thomas, 05

Rau, J. V., 02
Robinson, Vance S., 05, 08

Ross, William R., 05

Sabia, E., 02

Salditt, Tim, 0I

Snigirev, A., 0J

Snigireva, I., 0]

Spa sso vsky, I. P., 02

Sto upin, Sta nislav, OE

Terentiev, S. A., 0J

Töpperwien, Mareike, 0

Umstadter, Donald, OG

van der Slot, P. J. M., 02

Verman, Boris, $\mathrm{OE}$

Yan, Wenchao, 0G

Zhang, Ping, OG

Zhao, Baozhen, OG

Zholudev, S. I., 0]

Zhou, Wei, OE

Zverev, D., 0] 
Proc. of SPIE Vol. $9964996401-6$

Downloaded From: https://www.spiedigitallibrary.org/conference-proceedings-of-spie on 26 Apr 2023 Terms of Use: https://www.spiedigitallibrary.org/terms-of-use 


\section{Conference Committee}

Program Track Chairs

Ali M. Khounsary, Illinois Institute of Technology (United States)

Ralph B. James, Brookhaven National Laboratory (United States)

Conference Chairs

Ali M. Khounsary, Illinois Institute of Technology (United States)

Gert E. van Dorssen, PANalytical B.V. (Netherlands)

Conference Program Committee

Mark A. Anastasio, Washington University in St. Louis (United States)

Sandra G. Biedron, Colorado State University (United States)

Jovan G. Brankov, Illinois Institute of Technology (United States)

Björn Hansson, Excillum AB (Sweden)

George A. Kyrala, Los Alamos National Laboratory (United States)

Carolyn A. MacDonald, University at Albany (United States)

Giovanni Pareschi, INAF - Osservatorio Astronomico di Brera (Italy)

Ladislav Pina, Czech Technical University in Prague (Czech Republic)

J. Scott Price, GE Global Research (United States)

Donald P. Umstadter, University of Nebraska-Lincoln (United States)

Session Chairs

1 Novel Laboratory X-Ray Sources I

Daniele Spiga, INAF - Osservatorio Astronomico di Brera (Italy)

J. Scott Price, GE Global Research (United States)

2 Novel Laboratory X-Ray Sources II

George A. Kyrala, Los Alamos National Laboratory (United States)

Donald P. Umstadter, University of Nebraska-Lincoln (United States)

3 Laboratory-based X-Ray Optics

Sandra G. Biedron, Colorado State University (United States)

Ali M. Khounsary, Illinois Institute of Technology (United States)

4 Laboratory-based X-Ray Applications

George A. Kyrala, Los Alamos National Laboratory (United States)

Ladislav Pina, Czech Technical University in Prague (Czech Republic) 
Proc. of SPIE Vol. $9964996401-8$

Downloaded From: https://www.spiedigitallibrary.org/conference-proceedings-of-spie on 26 Apr 2023 Terms of Use: https://www.spiedigitallibrary.org/terms-of-use 